(C) 1984. The Genetical Society of Great Britain

\title{
INTRASPECIFIC VARIATION IN NUCLEAR DNA CONTENT IN COLLINSIA VERNA NUTT. (SCROPHULARIACEAE)
}

\author{
JUDITH K. GREENLEE, K. S. RAI* AND ALTON D. FLOYD $\dagger$ \\ Department of Biology, University of Notre Dame, Notre Dame, Indiana USA*; Department \\ of Pathology, Indiana University Medical Center, Indianapolis, Indiana USA† \\ Received 8.vi.83
}

\section{SUMMARY}

Intraspecific variation in nuclear DNA amount was found among 12 field populations of Collinsia verna (Scrophulariaceae). Nearly a four fold difference in DNA amount was found among populations collected from a 300 mile area of the mid-west United States. Genetic isolation and microhabitat differences are suggested causes of this high degree of genetic differentiation, and possible incipient speciation.

\section{INTRODUCTION}

Species in the genus Collinsia are widely distributed across the United States, but are mainly concentrated in the west coast states. Twenty-two species occur in the United States, and 19 of these are found on the west coast, one in the northern U.S. and southern Canada ( $C$. parviflora), one in the middle and south-eastern U.S. (C. violacea), and one species in the northern mid-west states $(C$. verna $)$. Collinsia occupies varying habitats from California mountain meadows to rocky outcroppings in New York (Rickett, 1966).

Collinsia verna (blue-eyed Mary) is an understory herb found on floodplains in the northern midwest (Garber, 1975). The population size of $C$. verna is generally very small and discontinuous with various populations often separated by several miles. Since such isolation seemingly precludes gene flow among various populations, the possibility of genetic differentiation leading to incipient speciation exists. Recently, $C$. verna populations were found to differ in several parameters including chiasmata frequencies, morphological characters and isozymic frequencies (Greenlee and Rai, 1983). The data from the above study showed considerable genetic divergence among populations. It was decided to extend these studies along another molecular parameter and to investigate the nuclear DNA amounts among the various populations. Measurable changes in the DNA can result from various sources, in particular, from changes in chromosomal number, deletions or duplications (Price, 1976), and aberrant replication of certain chromosomal segments (Keyl, 1965).

DNA values as determined by Feulgen cytophotometry constitute an important parameter which has been used as an investigative technique to determine quantitative genomic changes across and within species. Until relatively recently, the premise used to be that DNA amounts varied among species, but were relatively constant within a species. However, studies have now revealed intraspecific variation as well (Price, 1976). Populations of C. verna were examined to determine their DNA values and explore further 


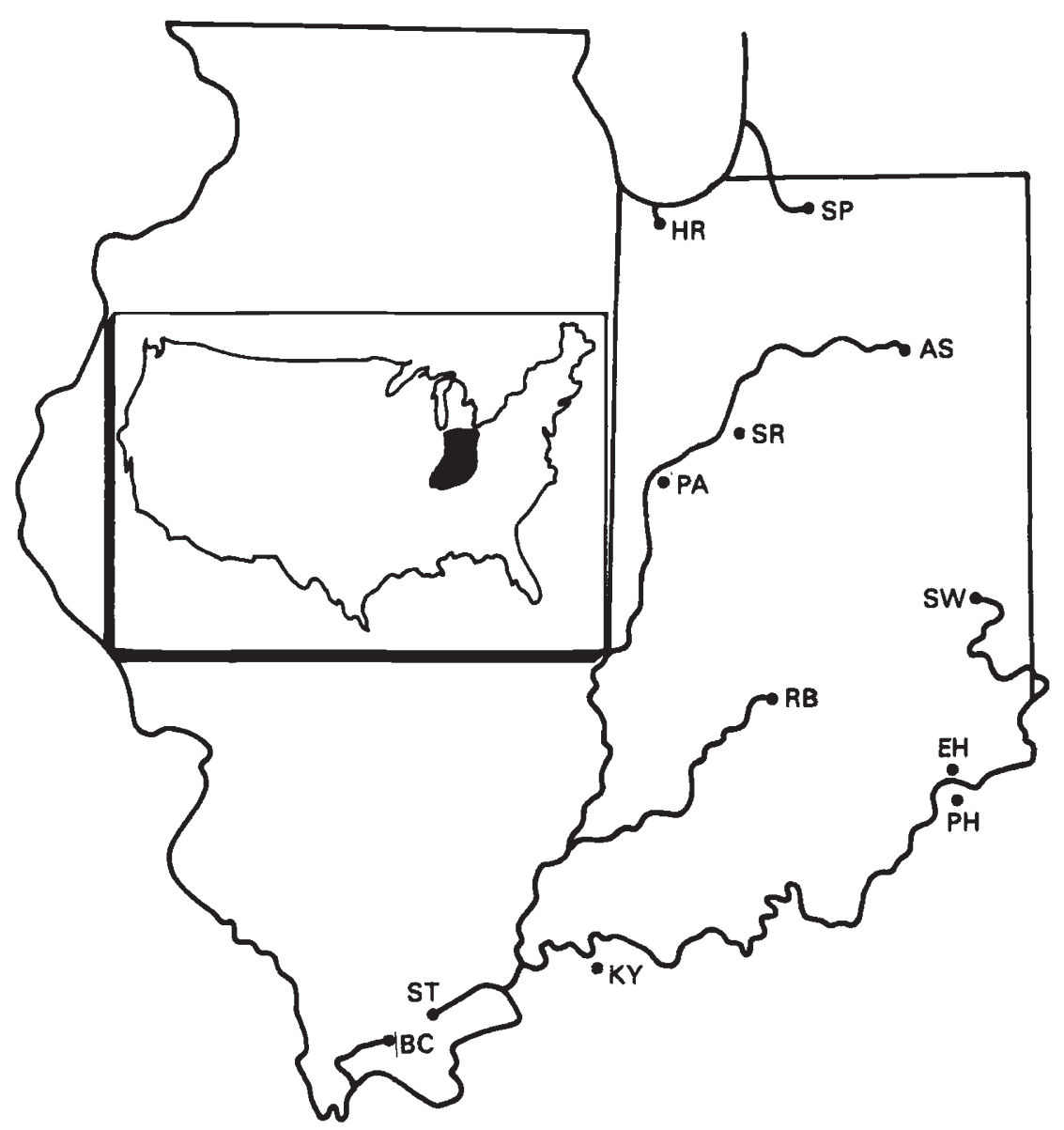

FIG. 1. Twelve populations were sampled and plants were grown in the greenhouse with environmental parameters which simulated natural conditions. Inset map of the United States shows shaded area of study. $H R=$ Heron Rookery; $\mathbf{S P}=$ Saint Patrick's; $A S=$ Asherwood; $\mathbf{P A}=$ Portland Arch; $\mathrm{SR}=$ Stare Road; SW = Schraeder-Weaver; $\mathbf{R B}=$ Riverbend; $\mathrm{EH}=$ Eagle Hollow; $\mathrm{PH}=$ Payne Hollow; KY = Henderson, Kentucky; ST = Stonefort; $\mathbf{B C}=$ Ballowe Church.

the extent of intraspecific variation. Two species of Collinsia which originated in California were also included in this study to determine interspecific variation.

\section{Materials AND METHODS}

Twelve populations of Collinsia verna were sampled in 3 midwestern states Indiana, Illinois and northern Kentucky (fig. 1). All populations were located on waterways and the major rivers involved are indicated on the map. Plants were collected when 2 to 5 centimeters high and returned to the greenhouse at the University of Notre Dame. They were individually potted and reared under controlled conditions which simulated the natural 
environment as far as temperature and day length are concerned. The two California species examined were $C$. tinctoria and $C$. heterophylla. The $C$. tinctoria populations have been grown in this laboratory for several years and these included a control (chromosomally normal) and a previously examined desynaptic mutant (Mehra and Rai, 1972). The seeds for the $C$. heterophylla population were kindly supplied by $\mathrm{Dr}$ R. W. Allard of the University of California at Davis and had been freshly field collected in 1981.

Feulgen cytophotometry was used to estimate relative amounts of DNA per cell nucleus in pollen mother cells from immature flower buds from populations of $C$. verna, $C$. heterophylla and $C$. tinctoria. The stained nuclei were measured at metaphase I and anaphase I cells were also measured as a check on the accuracy of half DNA values compared with whole cell measurements. A Zeiss MPM-01 cytophotometer was used to make measurements by the two wavelength method (Berlyn and Miksche, 1976). One hundred readings from two to four plants per population were taken. Calculation of relative Feulgen units was by the method of Ornstein (1952) via a computer adaptation (Floyd, personal communication) which was adapted and changed to Basic computer language for use with a freestanding 4051 Tektronix terminal. Slides of Allium cepa root tips were concurrently stained and used as a standard (Bennett, 1976) to convert the relative Feulgen units to picograms of DNA.

The Feulgen staining procedure was an adaptation of the method described by Berlyn and Miksche (1976). Slides were prepared from buds collected and fixed in 6: 3:2 ethanol: chloroform: propionic acid. Buds were rinsed in water, anthers dissected in 45 per cent acetic acid, squashed, coverslips removed by liquid Nitrogen, slides dipped in absolute alcohol and air dried. Slides of root tips of Allium were prepared the same way. All slides were stored in a dessicator until stained.

DNA values were analyzed by One Way ANOVA with Feulgen units as the response variable and populations as the treatment. Duncan's Multiple Range Test was used to group populations into homogeneous subsets.

\section{RESULTS}

The results of the One Way ANOVA and Duncan's Test are shown in table 1. The ANOVA was significant at the $p<0.0001$ level. Also tabulated are the calculations using Allium cepa as a standard which allowed comparison across two staining batches, those previously done with $C$. tinctoria and $C$. heterophylla and the group of $C$. verna populations. The calculations of DNA values in picograms are also shown. DNA amounts are shown graphically in fig. 2. The highest value was $28.56 \mathrm{pg}$ DNA in the Saint Patrick's population and the lowest was $7 \cdot 35$ pg DNA in the Henderson, Ky. population. Groups from Duncan's Test were overlapping. Saint Patrick's was in the highest group. Ballowe Church and Heron Rookery were the next highest and then a large drop in DNA value occurred across the rest of the populations. No obvious geographic trend in DNA values was seen. The $C$. heterophylla and two $C$. tinctoria populations were near the lower end of the range of the $C$. verna values, and were not significantly different from each other. 
TABLE 1

Groups shown are significantly different using $p<0.05$ with Duncan's Multiple Range Test. (DNA values determined by Feulgen cytophotometry)

\begin{tabular}{|c|c|c|c|c|}
\hline \multirow[t]{2}{*}{ Population } & \multirow[t]{2}{*}{ Feulgen units } & \multirow[t]{2}{*}{ DNA picograms } & \multicolumn{2}{|c|}{$\begin{array}{l}\text { Duncan's } \\
\text { groups }\end{array}$} \\
\hline & & & & \\
\hline Saint Patrick's & 678 & $28 \cdot 56$ & $\mathbf{A}$ & \\
\hline Ballowe Church & 666 & $24 \cdot 74$ & B & \\
\hline Heron Rookery & 657 & $24 \cdot 40$ & B & \\
\hline Eagle Hollow & 579 & $21 \cdot 50$ & B & \\
\hline Stonefort & 475 & $17 \cdot 64$ & C & \\
\hline Riverbend & 468 & $17 \cdot 38$ & C & \\
\hline Stare Road & 417 & 15.49 & $\mathrm{C}$ & D \\
\hline Portland Arch & 383 & $14 \cdot 22$ & & D \\
\hline Payne Hollow & 347 & $12 \cdot 89$ & & D \\
\hline Asherwood & 278 & $10 \cdot 32$ & $\mathrm{E}$ & \\
\hline Schraeder-Weaver & 255 & $9 \cdot 47$ & $\mathbf{E}$ & $\mathrm{F}$ \\
\hline Henderson, Ky. & 198 & $7 \cdot 35$ & & $\mathrm{~F}$ \\
\hline \multicolumn{5}{|l|}{ C. tinctoria } \\
\hline control & 307 & $11 \cdot 40$ & E & \\
\hline desynaptic mutant & 286 & $10 \cdot 62$ & E & \\
\hline C. heterophylla & 285 & $10 \cdot 58$ & E & \\
\hline
\end{tabular}

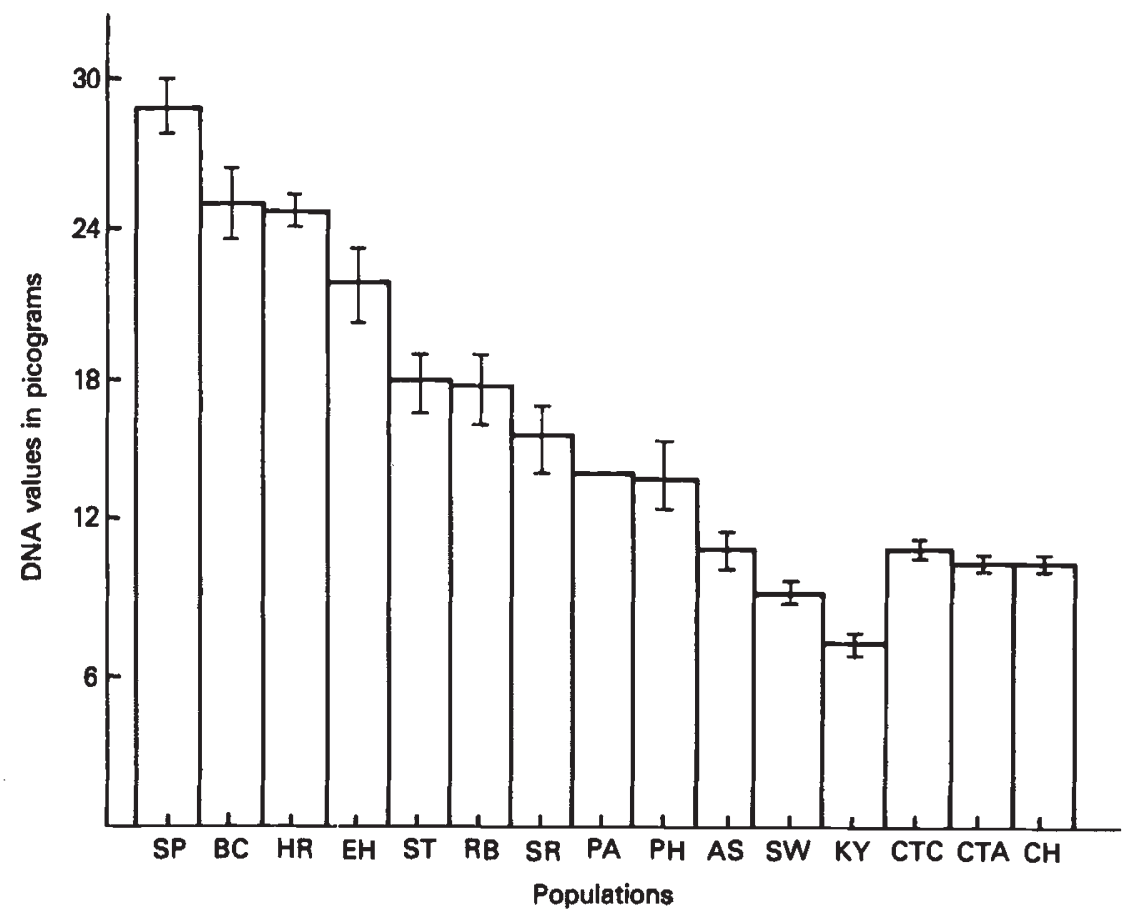

Fig. 2. C. verna: $\mathrm{SP}=$ Saint Patrick's, $\mathrm{BC}=$ Ballowe Church, $\mathrm{HR}=$ Heron Rookery, $\mathrm{EH}=$ Eagle Hollow, $\mathrm{ST}=$ Stonefort, $\mathrm{RB}=$ Riverbend, $\mathrm{SR}=$ Stare Road, PA $=$ Portland Arch, $\mathrm{PH}=$ Payne Hollow, $\mathrm{AS}=$ Asherwood, $\mathrm{SW}=$ Schraeder-Weaver, $\mathrm{KY}=$ Henderson, Kentucky; $C$. tinctoria: $\mathrm{CTC}=$ control, $\mathrm{CTA}=$ desynaptic mutant; $\mathrm{CH}=C$. heterophylla. 


\section{Discussion}

Previously reported estimated nuclear DNA values have been compiled for approximately 1000 species of angiosperms (Bennett and Smith, 1976; Bennett, Smith and Heslop-Harrison, 1982). A 600 fold difference has been found across all angiosperm species reported, with absolute haploid values ranging from $0.2 \mathrm{pg}$ to $127.4 \mathrm{pg}$ DNA. A large amount of variation is known to exist within families of Angiosperms such as Ranunculaceae (Rothfels et al., 1966); Droseraceae (Rothfels and Heimburger, 1968); among genera and species in Graminae (Bennett, 1972; Rees and Jones, 1967; Sparrow and Nauman, 1974); Leguminosae (Rees and Hazarika, 1967; Chooi, 1971; Bennett, 1972); Compositae (Wallace, Sparkes and Maden, 1972; Price and Bachman, 1975). However, in the family Scrophulariaceae Bennett et al., (1982) list only one species out of 240 and the list of Bennett and Smith in 1976 contains only two species of Schrophulariaceae out of 753 species. Obviously, relatively little work has been published on this family as far as nuclear DNA amounts are concerned.

The amount of DNA in the genome has been correlated with several variables, such as length of the mitotic cycle (Van't Hof and Sparrow, 1963), length of the male meiotic cycle (Bennett, 1971; Bennett and Smith, 1972), and the minimum length of generation time (Bennett, 1972; Smith and Bennett, 1975), the effects of radiation exposure (Sparrow and Miksche, 1961), and rates of radiation induced mutation (Sparrow et al., 1968). Crop plants with higher DNA amounts are found mostly in temperate latitudes with this distribution pattern being observed in $\mathrm{C} 3$ and $\mathrm{C} 4$ plants, and annuals and perennials (Bennett, 1976). These specific effects may not directly apply to the Collinsia verna populations, but they demonstrate that a wide range of environmental effects have been linked to changes in DNA amounts.

DNA increases and decreases have a major role in evolution. These changes and individual nucleotide changes are seen in two of the most important modifications contributing to evolutionary change (Hinegardner, 1976). Low amounts of DNA are correlated with specialisation in animals (Bachman et al., 1972; Stebbins, 1966; Hinegardner, 1968) and in plants (Stebbins, 1966).

Increases in the amount of DNA have been shown by a wide range of studies. Single genes have been shown to be present in duplicate copies such as the hemoglobin genes (Zuckerkandl, 1965). Also, in eukaryotic genomes examined, highly repetitive sequences are found (Davidson and Britten, 1973). Some of these repetitive sequences are duplicated 1000 to 5000 times and some very simple repeat sequences occur as $1,000,000$ or more times in the genome (Galau et al., 1976). Although the function of these highly repetitive sequences are unclear, it is known that many of them are not transcribed into mRNA (Constatini et al., 1980).

When DNA amounts were first reported, many investigators held the opinion that DNA val'ses differed between species but that within a species DNA values were relatively constant. However, more recent studies have shown considerable intraspecific variation (Price, 1976). In certain instances, such variation, such as that found within a flax strain (Evans, 1968) is due to environmental differences, and could be influenced by low temperatures (Durrant and Jones, 1971). Intraspecific DNA variations correlated with 
latitude changes have been shown in Picea (Miksche, 1968, 1971) and in cereal crops (Bennett, 1976). DNA increases in populations of Pseudotsuga menziesii were found along a geographical cline from coastal to interior regions (El-Lakany and Sziklai, 1970). In both the latter cases variation in climate was a proposed factor in the change.

Accumulation of small deletions or duplications has also been proposed as a mechanism for changes in DNA amounts (Price, 1976). The presence of megachromosomes (enlargement of one or more chromosomes) has been proposed as a mechanism of DNA increase (Gerstel and Burns, 1967). While it has been proposed that differential increases in heterochromatin are correlated with these DNA increases, Dhillon et al., (1981) have shown DNA changes among the strains of Ocimum basilicum without associated proportional increases in ratios of heterochromatin to euchromatin.

In Collinsia the pattern of spread of the species is probably from the west coast of the United States, which has twenty species, eastward, where only three species are found in the remaining states. This suggests that the ancestral species to Collinsia verna may have evolved from a west coast species. Collinsia heterophylla and C. tinctoria, the two California species, show approximately $10 \cdot 5$ to $11.4 \mathrm{pg}$ DNA per $4 \mathrm{C}$ nucleus. Evolutionarily, increasing DNA amounts are proposed to be more advantageous than decreasing DNA amounts (Hinegardner, 1976) and most of the $C$. verna populations are at or above the DNA amounts of the California species. If the $C$. verna species is more recently evolved than the California species and since it has to adapt to climatic changes in the midwest, the increases in DNA amounts could be an adaptive mechanism in response to environmental changes (Miksche, 1968, 1971; Evans, 1968; Durrant and Jones, 1971; El-Lakany and Sziklai, 1970). It is also possible that if several populations of $C$. heterophylla and $C$. tinctoria were measured, variability among those populations might also be detected.

Geographically, the two northern populations showed the highest (Saint Patrick's) and the third highest (Heron Rookery) DNA values. The second highest was Ballowe Church which is located in southern Illinois. The other values also show no obvious geographic trend. For example, SP and AS, although geographically quite close, show a 2.5 fold difference in their DNA values. Unlike those previously cited studies, no definite trend or cline in DNA values seemed to be present. In conjunction with this, micro-environmental differences, such as those which have been shown to cause intraspecific isozymic changes (Brown, 1979) could also be a factor in change in DNA content. DNA values in previously cited studies have been shown to be affected by a wide range of environmental factors and it is proposed that the microhabitat differences which are purported causes of other types of genetic variation could also be contributing to the DNA value changes seen in Collinsia verna populations. Alternatively, the observed changes may also represent random changes resulting from the proposed "molecular drive", which is defined by Dover as an "unusual fixation" in the genome. Possibly, this type of fixation could contribute to "accidental speciation" by maximising cohesiveness of genetic parameters within a population, while maximising discontinuities between populations (Dover, 1982). While the pattern or determining factors are not entirely clear, the nearly 4 fold differences in DNA values combined with the parametric differences previously found in chiasmata frequencies, morphological measurements and 
electromorph frequencies (Greenlee and Rai, 1983), clearly show that genetic differentiation has occurred among these Collinsia verna populations.

Acknowledgements. The authors acknowledge support for this work from the Indiana Academy of Sciences, the Office of Advanced Studies University of Notre Dame and the Arthur J. Schmitt Foundation.

\section{REFERENCES}

BACKMAN, K., HARRINGTON, B. A. AND CRAIG, J. P. 1972. Genome size in birds. Chromosoma, 37, 405-416.

BennetT, M. D. 1971. The duration of meiosis. Proc, Roy. Soc. Lond. B., 178, 277-299.

BENNETT, M. D. 1972. Nuclear DNA content and minimum generation time in herbaceous plants. Proc. Roy. Soc. Lond. B., 181, 109-135.

BENNETT, M. D. 1976. DNA amount, latitude and crop plant distribution. Env. and Exp. Bot., 16, 93-108.

BENNETT, M. D. AND SMITH, J. B. 1972. The effects of polyploidy on meiotic duration and pollen development in cereal anthers. Proc. Roy. Soc. Lond. B., 181, 81-107.

BENNETT, M. D. AND SMITH, J. B. 1976. Nuclear DNA amounts in angiosperms. Phil. Trans. Roy. Soc. Lond. B., 277, 201-226.

BENNETT, M. D., SMITH, J. B. AND HESLOP-HARRISON, J. S. 1982. Nuclear DNA amounts in angiosperms. Proc. Roy. Soc. Lond. B., 216, 179-199.

BERLYN, G. P. AND MIKSCHE, J. P. 1976. Botanical Microtechniques and Cytochemistry. The Iowa State Univ. Press. Ames.

BROWN, A. H. D. 1979. Enzyme polymorphism in plant populations. Theor. Pop. Genet., 15, $1-42$.

CHOOI, W. Y. 1971. Variation in nuclear DNA content in the genus Vicia. Genetics, 68, 195-211.

CONSTANINI, F. D., BRITTEN, R. J. AND DAVIDSON, E. H. 1980. Message sequences and short repetitive sequences are interspersed in sea urchin egg poly $(A)+$ RNA's. Nature, 287,111 .

DAVIDSON, E. H. AND BRITTEN, R. J. 1973. Organization, transcription and regulation in the animal genome, Quart. Rev. Biol., 48, 565-613.

DHILLON, S. S., MIKSCHE, J. P. AND LAWRENCE, B. M. 1981. Inter and intrastrain variation in DNA content of Ocimum basilicum. Bot. Soc. Am., Misc. Ser. Publ., 160, 8.

DOVER, G. 1982. Molecular drive: a cohesive mode of species evolution. Nature, 299,111-116.

DURRANT, A. AND JONES, T. W. A., 1971. Reversion of induced changes in the amount of nuclear DNA in Linum. Heredity, 27, 431-439.

EL-LAKANY, M. H. AND O. SZIKLAI. 1970. Variation in nuclear characteristics in selected western conifers and its relation to radiosensitivity. Radiation Botany, 10, 421-427.

FLOYD, A. D. 1980. DNA calculation program in PL-1. Personal communication.

EVANS, G. M. 1968. Nuclear changes in flax. Heredity 23, 25-38.

GAlAU, G. A., CHAMBERLIN, M. E., HOUGH, B. R., BRITTEN, R. J. AND DAVIDSON, E. H. 1976. Evolution of repetitive and nonrepetitive DNA. In Ayala, F. J., (ed.) Molecular Evolution. Sinauer Assoc., Inc. Sunderland.

GARBER, E. D. 1975. Collinsia. In King, R. C. (ed.) Handbook of Genetics, vol. 2. Plenum Press, New York.

GERSTEL, D. V. AND BURNS, J. A., 1967. Phenotypic and chromosomal abnormalities associated with the introduction of heterochromatin from Nicotiana otophora into N. tabacum. Genetics, 56, 483-502.

GREenleE, J. K. AND RAI, K. S. 1983. Population differentiation in Collinsia verna Nutt. (Scrophulariaceae): A multifaceted approach. Manuscript submitted.

HINEGARDNER, R. 1968. Evolution of cellular DNA content in teleost fishes. Amer. Natur., $102,517-523$.

HINEGARDNER, R. 1976. Evolution of genome size. In Ayala, F. J. (ed.) Molecular Evolution. Sinauer Assoc., Inc. Sunderland.

KEYL, H. G. 1965. Duplikationen von Untereinheiten der chromosomalen DNA während der Evolution von Chironomus thummi. Chromosoma, 17, 139-180.

MEHRA, R. C. AND RAI, K. S. 1972. Cytogenetic studies of meiotic abnormalities in Collinsia tinctoria. II. Desynapsis. Can. J. Genet. Cytol, 14, 637-644. 
MIKSCHE, J. P. 1968. Quantitative study of intraspecific variation of DNA per cell in Picea glauca and Pinus banksiana. Can J. Genet. Cytol., 10, 590-600.

MIKSCHE, J. P. 1971. Intraspecific variation of DNA per cell between Picea sitschensis (Bong.) Carr. Provenances. Chromosoma, 32, 343-352.

ORNSTEIN, L. 1952. The distributional error in microspectrophotometry. Lab. Invest., 1, 250-262.

PRICE, H. J. 1976. Evolution of DNA content in higher plants. The Botanical Review, 42(1), 27-52.

PRICE, H. J. AND BACHMAN, K. 1975. DNA content and evolution in Microseridinae. Amer. J. Bot., 62, 262-267.

REES, H. AND HAZARIKA, M. H. 1967. Chromosome evolution in Lathyrus. In Darlington,

C. D. and Lewis, K. R. (eds) Chromosomes Today, vol. 2. Plenum Press, New York.

REES, H. AND JONES, G. H. 1967. Chromosome evolution in Lolium. Heredity, 22, 1-18.

RICKETT, W. H. (ed.) 1966. Wildflowers of the United States, vol. 1, Part 2. McGraw Hill Book Co., New York. 401-402.

ROTHFELS, K. AND HEIMBERGER, M. 1968. Chromosome size and DNA values in sundews (Droseraceae). Chromosoma, 20, 54-74.

ROTHFelS, K., SEXSMiTH, E., HEIMBERGER, M. AND KRAUSE, M. O. 1966. Chromosome size and DNA content of species of Anemone L. and related genera (Ranunculaceae). Chromosoma, 20, 54-74.

SMITH, J. B. AND BENNETT, M. D. 1975. DNA variation in the genus Ranunculus. Heredity, $35,231-239$.

SPARROW, A. H., BAETCKE, K. P., SHAVER, D. L. AND POND, V. 1968. The relationship of mutation rate per roentgen to DNA content per chromosome and to interphase chromosome volume. Genetics, 59, 65-78.

SPARROW, A. H. AND MIKSCHE, J. P. 1961. Correlation of nuclear volume and DNA content with higher plant tolerance to chronic radiation. Science, 134, 282-283.

SPARROW, A. H. AND NAUMAN, A. F. 1974. Evolutionary changes in genome and chromosome sizes and in DNA content in the grasses. Brookhaven Symp. Biol., 25, 367-389.

STEBBINS, G. L. 1966. Chromosomal variation and evolution. Science, 152, 1463-1469.

VAN'T HOF, J. AND SPARROW, A. H. 1963. A relationship between DNA content, nuclear volume and minimum mitotic cycle time. P.N.A.S. USA, 49, 897-902.

WALLACE, H., SPARKES, C. A. AND MADEN, M. 1972. Nuclear DNA content of three Crepis species. Heredity, 29, 367-373.

ZUCKERKANDL, E. 1965. The evolution of hemoglobin. Sci. Amer. 212, (5), 110-118. 